\title{
Review
}

\section{Distribution, exposure pathways, sources and toxicity of nonylphenol and nonylphenol ethoxylates in the environment}

\author{
TB Chokwe'*, JO Okonkwo ${ }^{2}$ and LL Sibali ${ }^{3}$ \\ 'Scientific Services, Rand Water, PO Box 3526, Vereeniging, 1930, South Africa \\ ${ }^{2}$ Department of Environmental, Water and Earth Sciences, Tshwane University of Technology, Pretoria, 0001, South Africa \\ ${ }^{3}$ Faculty of Applied Sciences, Cape Peninsula University of Technology, Cape Town, 8001, South Africa
}

\begin{abstract}
Alkylphenols (APs) are ultimate breakdown products of alkylphenol polyethoxylate (APEs) that are used in cleaning and industrial processes. The most commonly used APEs in the market are the nonylphenol ethoxylates (NPEs) and octylphenol ethoxylates (OPEs). As a result of their widespread use and their lipophilic nature, these compounds are ubiquitous in the environment and are currently of concern because of their toxicity, oestrogenic properties and widespread contamination. This review summarizes the concentrations of NPE and NP in different environmental media. The sources of NPE in the environment and toxicity are reviewed. Their distribution patterns in the environment as well as exposure pathways are discussed with a view to provide better understanding of these emerging environmental contaminants. It is envisaged that this review will heighten the importance of identifying emerging issues and data gaps, and generate a future research agenda on APEs.
\end{abstract}

Keywords: nonylphenols, nonylphenol ethoxylates, concentrations, exposure pathway, sources, toxicity

\section{INTRODUCTION}

Surfactants are a diverse group of chemicals that are designed to have cleaning or solubilization properties (Ying, 2006). They generally consist of a polar group which is well solvated in water and a nonpolar hydrocarbon group which is not easily dissolved in water. Hence, surfactants combine both hydrophobic and hydrophilic properties in one molecule (Ying, 2006; Olkowska et al., 2014). Based on the hydrophobic part of their molecules, surfactants may be classified as cationic, nonionic and/ or anionic compounds (Olkowska et al., 2014). Nonionic surfactants, such as alkylphenol ethoxylates (APEs), are one of the most widely used classes of surfactants. They have been used as detergents and emulsifiers in domestic, industrial and institutional applications, including paper production, leather and textile processing, and cleaning detergents. Also, some examples of this type of surfactant have been used in pesticide formulation (Datta et al., 2002; Ying et al., 2002; Kannan et al., 2003; Siemering et al., 2008; Xie and Ebinghaus, 2008; Bjorkland et al., 2009). The most important members of APEs are nonylphenol ethoxylates (NPEs) and octylphenol ethoxylates (OPEs), which account for approximately $80 \%$ and $20 \%$ of total APEs production, respectively (Keith et al., 2001; Diaz et al., 2002; Chiu et al., 2010). The chemical structures of these compounds are illustrated in Fig. 1.

Concern has increased about relatively stable degradation products of APEs, alkylphenols (APs) such as nonylphenol (NP) and octylphenol (OP) (Zhang et al., 2009). APs have been classified together with lower ethoxylates (mono- tri), as endocrine-disrupting compounds (EDCs), because of their effects on the hormonal system of numerous organisms by

To whom all correspondence should be addressed.

용 +27 164308420 ; fax: +27 164552055 ;

e-mail: tchokwe@randwater.co.za; tlouchokwe6@gmail.com Received 14 December 2016; accepted in revised form 24 August 2017 competing with oestrogen for binding receptors (Gibble and Baer, 2003; Bonefeld-Jorgensen et al., 2007). Exposure to the aquatic ecosystem is of particular concern, since aquatic organisms are exposed to continual introduction of discharged effluents from wastewater treatment works (WWTWs) (Olujimi et al., 2010). Moreover, the polar and non-volatile nature of these compounds prevents their escape from the aquatic realm (Xu et al., 2006). For this reason, NPs and OPs have been phased out in most developed countries and have been designated as priority substances in the Water Framework Directive (Directive 2000/60/EC 2000), and most of their uses are currently regulated (Directive 2003/53/EC 2003). However, in many developing countries, such as those in Africa and Asia, uncontrolled domestic and industrial discharge to waterways contributes to the high levels of EDCs in the aquatic environment (Falconer et al., 2006; Peng et al., 2006), and no schedule has been designed to reduce the use of NP, and use of APEs is these countries may be increasing. For example, the production of NP in 2001 reached approximately $16000 \mathrm{t}$ in China (Jin et al., 2004) increasing to $31434 \mathrm{t}$ in 2011 (Gao et<smiles>CCCCCCCCc1ccc(OCC(C)(C)O)cc1</smiles>

NPnEOS<smiles></smiles>

NP<smiles>CC(C)(O)COc1ccc([18CH][18CH])cc1</smiles>

OPnEOs

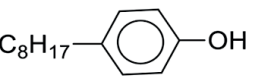

OP
Figure 1

Structures of nonyl- and octylphenol ethoxylates (top left and right) and their metabolites nonylphenol (NP) and octylphenol (OP) (bottom left and right) 
al., 2014). This increase accounted for $10 \%$ of total world NP production, according to the records of the China Petroleum and Chemical Industry (Gao et al., 2014). Thus, monitoring of NP in the environment becomes of particular concern because (i) both the NP and its parent compound, NPE, are ubiquitous in the environment, (ii) these compounds indicate a long-term environmental contamination, and (iii) they have shown to be toxic to aquatic organisms. The strong evidence of increasing contamination of the environment by these compounds heightens the importance of identifying emerging issues and data gaps. This review, therefore, focuses on sources, distribution in the environment, exposure pathways, and toxicity of APEs.

\section{SOURCES OF APES IN THE ENVIRONMENT}

Environmental release of APEs may occur during their initial synthesis, incorporation into related finished products for use, or as a result of their ultimate disposal or recycling. Nonylphenol and other alkylphenols are synthesized from intermediates in the refinement of petroleum and coal-tar (Núñez et al., 2007). Technical preparation of nonylphenol is a complex mixture of several branched alkyl isomers (VazquezDuhalt et al., 2005). The process for the manufacture of alkylphenols is presented in Fig. 2.

Similarly, the synthesis of alkylphenol ethoxylates involves ethoxylation of branched octyl- or nonyl- phenols using ethylene oxide, resulting in isomers (with different alkyl moieties) and oligomers with different numbers of ethoxylate units (De Voogt et al., 1997).

Discharges from wastewater treatment works (WWTW) has been identified as another major source of APEs and their degradation products to aquatic environments (Fujita et al, 2000; Farre et al., 2002; Rice et al., 2003; Esperanza et al., 2004; Jensen and Jepsen, 2005; Johnson et al., 2005; Gatidou et al., 2007; Ying et al., 2008, 2009; Diehl et al., 2012; Chokwe et al., 2015a). Reported removal efficiency of APEs in sewage treatment works varies between 9 and $94 \%$, depending on the region and type of unit treatment process (Jensen and Jepsen, 2005; Johnson et al., 2005). These results are of concern as they indicate that sewage treatment works are only partially efficient in removing such compounds. Primary degradation of APEs in sewage treatment works or in the environment generates more persistent shorter-chain APEs and alkylphenols (APs), such as NP, OP and AP mono- to triethoxylates (NPE1, NPE2, NPE3) (Giger et al., 1984; Ying et al., 2002; Langford et al., 2005). Short-chain APEs, such as NP1E and NP2E, have been analysed in a few studies and are often present in effluents at concentrations higher than their respective alkylphenols (i.e. NP) due to their higher water solubility (Glassmeyer et al., 2005; Loyo-Rosales et al., 2007). Further transformation proceeds via oxidation of the EO chain, producing mainly alkylphenoxy ethoxy acetic acid and alkylphenoxy acetic acid. The general degradation pathway of these compounds is presented in Fig. 3.

Biodegradation of longer-chain NPEs is readily achievable, but ultimate biodegradation of NP1EO, NP2EO, carboxylate derivatives and NP is considerably slower (Health Canada, 2001). The lower rate of biodegradation indicates that these pollutants have the capacity to accumulate in organisms and be transferred between trophic levels, thus leading to a stepwise increase in contamination.

\section{ANALYSIS OF ALKYLPHENOL ETHOXYLATES IN THE ENVIRONMENT}

In terms of sample preparations, several techniques have been reported for the isolation of APEs from matrices. For liquid samples, liquid-liquid extraction (Tsuda et al., 2000; Espejo et al., 2002), and solid phase extraction (Chen et al., 2006; Koh et al., 2008; Chokwe et al., 2012), as well as solid-phase microextraction (Pan and Tsai, 2008), have been used. The use of large amounts of generally toxic solvents, and formation of emulsion as well as loss during chromatographic clean-up of extracts derived from liquid-liquid extraction has made the techniques less popular for isolation of APEs in liquid samples. The use of solid-phase extraction (SPE) has received much attention as it is used as a pre-concentration and purification step at the same time. Selection of SPE cartridges with a particular sorbent material such as porous silica bonded with C18 or other hydrophobic alkyl groups such as styrenedivinylbenzene, plays an important role in the achievement of reproducible recoveries of analytes in liquid samples (Gilart et al., 2014).

For solid samples, extraction methods such as microwaveassisted extraction (Fountoulakis et al., 2005), Soxhlet extraction (Sibali et al., 2010), pressurized liquid extraction (Fiedler et al., 2007), and ultrasonic-assisted extraction (Núñez et al., 2007) have been employed for the isolation of NP, NPE1, NPE2 and NPPE. Due to the fact that some of these techniques are too sophisticated or expensive, Soxhlet extraction has been the method of choice for the isolation of APEs in environmental solid matrix (Sibali et al., 2010), though the use of ultrasonic-assisted extraction is becoming more popular (Núñez et al., 2007; Chokwe et al., 2015a, 2016). Prior to extraction, solid samples are dried and homogenized

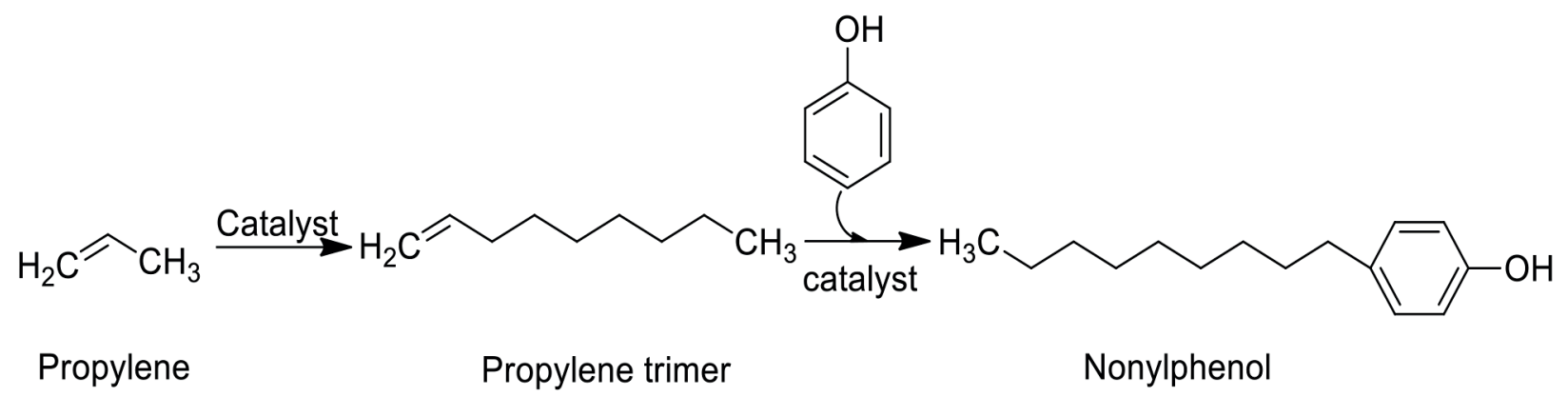

Figure 2

Chemical synthesis of nonylphenol 


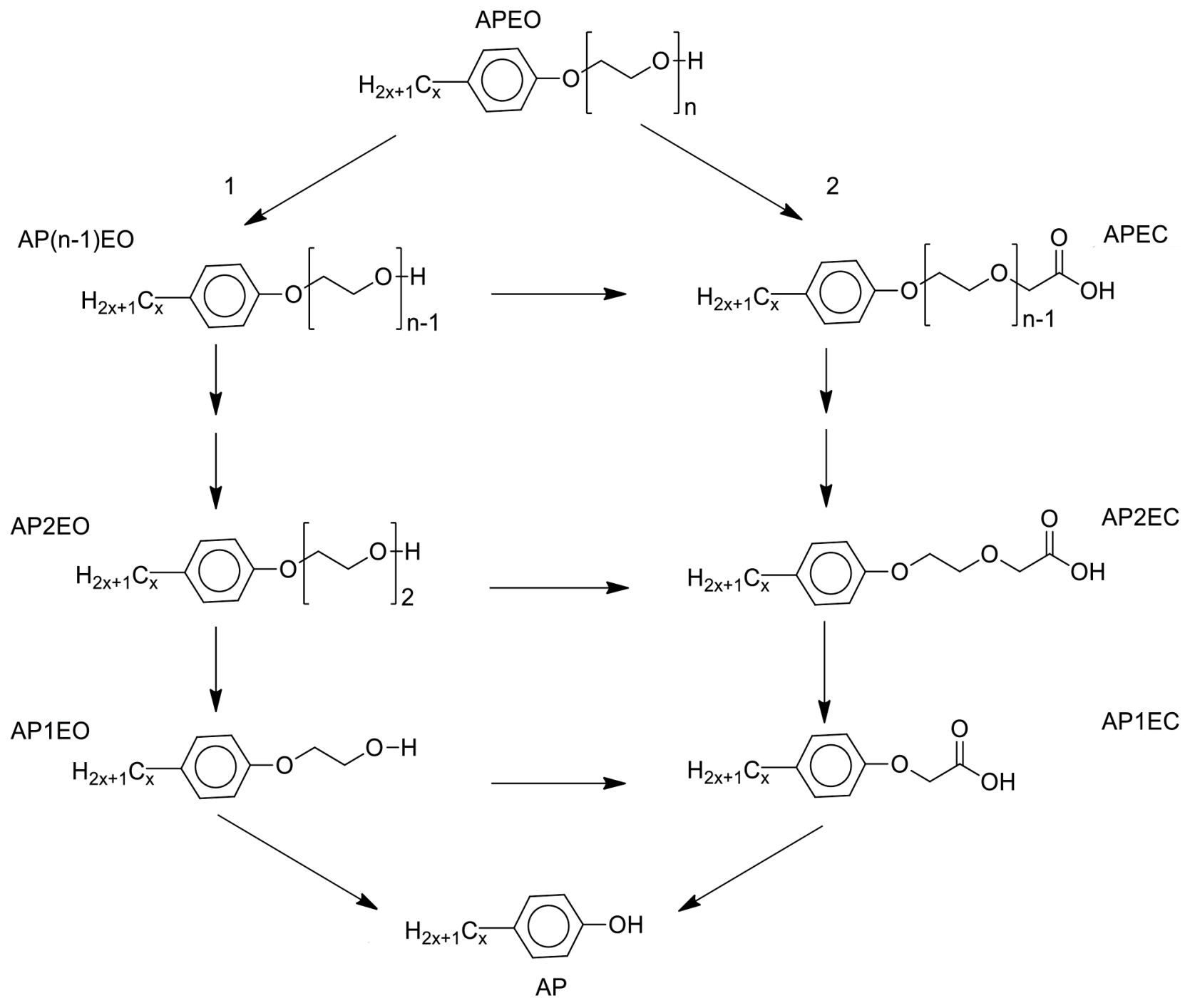

Figure 3

Degradation pathway of APEs (Renner, 1997)

by air-drying or freeze drying, or by mixing with anhydrous sodium sulphate until free flow is obtained. The extracts obtained are purified further by column chromatography or SPE before instrumental analysis.

Separation and identification of APEs in environmental media has been achieved by either high-performance liquid chromatography (HPLC) or gas chromatography (GC) (Lu and Gan, 2014). With both instruments, a mass spectrometer detector (MSD) was the most commonly used detector for quantifying the APEs (Wu et al., 2010; Chokwe et al., 2012). A flame ionization detector (FID) has been used in some instances for the quantification of APEs in the environment (Güenther et al, 2006; Sibali et al., 2010; Guruge et al, 2011). Tandem mass spectrometry (MS/MS) has been used to detect trace amounts of these pollutants in the environment (SchmitzAlfonso et al., 2003; Shao et al., 2005, 2007; Moeder et al., 2006). The polarity of phenols affects their chromatographic resolution and usually results in broad or tailored peaks (Olujimi et al., 2010). A widely used instrumentation for the analysis of APEs in the environment has been GC after the derivatization of the hydroxyl group (Cathum \& Sabik, 2001; Gatidou et al., 2007; Fiedler et al., 2007). Several derivatization methods such as acetylation, alkylation and silylation have been used for GC analysis of phenolic compounds. For example, HFBA was used as a derivatizing agent for the determination of APE and BFR analytes in environmental samples (Chokwe et al., 2012, 2014). In another study, NP and BPA were derivatized within $30 \mathrm{~min}$ at $60^{\circ} \mathrm{C}$ using TFAA (Stehmann and Schröder, 2004). Derivatization of NPEO with $n$-propanol-acetyl chloride at $80^{\circ} \mathrm{C}$ for $1 \mathrm{~h}$ has also been reported (Ding and Tzing, 1998). Cathum and Sabik (2001) described a derivatization procedure for APEO using pentafluorobenzoyl bromide (PFB-Br) as derivatizing agent, aided with $\mathrm{K}_{2} \mathrm{CO}_{3}$ by sonication. The derivatization took $2 \mathrm{~h}$ and was conducted in the dark. Gatidou et al. (2007) reported derivatization of NP, NP2EO, BPA and triclosan with bistrimethylsilylfluoroacetamide (BSTFA) at $65^{\circ} \mathrm{C}$ for 20 min while Fiedler et al. (2007) derivatized APs with the same reagent at room temperature for $2 \mathrm{~h}$. Furthermore, NPEO was derivatized with BSTFA in the presence of trimethylchlorosilane (TMCS) at $70^{\circ} \mathrm{C}$ for $4 \mathrm{~h}$ (Esperanza et al., 2004). In a separate study, Hoai et al. (2003) reported derivatized NPEOs and NPECs with bistrimethylsilylacetamide (BSA) at $25^{\circ} \mathrm{C}$ for $1 \mathrm{~h}$. 


\section{DISTRIBUTION OF APES IN THE ENVIRONMENT}

APEs make up the world's third-largest group of surfactants in terms of production, and have been used widely in the industry for over 50 years (Ying et al., 2002; Koniecko et al., 2014). Their behaviour in the environment is influenced by their physicochemical properties (Ying et al., 2002). The solubility of an APE surfactant depends on the number of polar groups forming the hydrophilic part of the molecule. Lower APE oligomers $(\mathrm{EO}<5)$ are usually described as 'water-insoluble' or lipophilic, whereas the higher oligomers are described as 'water-soluble' or hydrophilic (Ahel and Giger, 1993). The solubility of OP1EO- OP4EO ranged from $8000-24500 \mu \mathrm{g} / \mathrm{L}$ in water, while solubility of OP was $12600 \mu \mathrm{g} / \mathrm{L}$ (Ahel and Giger, 1993). NP has a water solubility of $5430 \mu \mathrm{g} / \mathrm{L}$ while the NP1EONP4EO have solubility ranging from $3020-9480 \mu \mathrm{g} / \mathrm{L}$. From these solubility values, the partition coefficients in the octanol/ water system and other logarithmic $\left(\log K_{\text {ow }}\right)$ values were calculated for OP, NP and NP1EO-3EO. The log $K_{\text {ow }}$ for these metabolites ranged from 3.90-4.48 suggesting that these substances are associated with the organic matter in sediments. These solubility and $\log K_{\text {ow }}$ results indicate that OP, NP, NP1EO- 3EO have large soil or sediment adsorption coefficients and a large bioaccumulation factor for aquatic life (Ying et al., 2002; Zhu and Zuo, 2013). The environmental fate assessment of OP and NP by Fugacity modelling showed that these pollutants occur at high levels in soil or sediments; lower levels occur in water and the lowest in air (Klosterhaus et al., 2012; Mao et al., 2012; Zhu \& Zuo, 2013; Chen et al., 2014; Chokwe et al., 2015a).

APEs presence in the environment is as a consequence of anthropogenic activities. The level of APs and APEs in the environment has been documented in many studies around the globe. NP, OP, octylphenol ethoxylates (OPEs) and NPEs have been detected in air, wastewater, surface water, sediment, sludge and biota samples (Rudel et al., 2003; Petrovic et al., 2003; Esperanza et al., 2004; Micic \& Hofmann, 2009; Zhang et al., 2009; Grund et al., 2011; Wang et al., 2012; Chokwe et al., 2015b). A schematic diagram showing the emission, distribution and exposure pathway is given in Fig. 4.

\section{Air}

Air concentrations of alkylphenols are rarely reported in the literature. Existing studies show that nonylphenol has been found in indoor environments in air and dust at concentrations higher than outdoor values (air - $100 \mathrm{ng} / \mathrm{m}^{3}$, and dust - $2580 \mathrm{ng} / \mathrm{g}$ ) (Rudel et al., 2003; Saito et al., 2004). Van Ry et al. (2000) reported gas-phase concentrations of nonylphenol and tert-octylphenol (tOP) at two sites in the lower Hudson River Estuary. NP concentrations ranged from ND to 56.3 and 0.13 to $81 \mathrm{ng} / \mathrm{m}^{3}$ for Sandy Hook and New Brunswick sites, respectively. The concentration range of tOP ranged from not detected (ND) to 1.0 and 0.01 to $2.5 \mathrm{ng} / \mathrm{m}^{3}$ for Sandy Hook and New Brunswick, respectively. NPs and tOP exhibited seasonal trends with higher gas phase concentrations during summer than during autumn and early winter. The results for NP were similar to the results reported by Dachs et al. (1999) from the same sampling points. Xie et al. (2006) reported a concentration range of 14 to $50 \mathrm{pg} / \mathrm{m}^{3}$ for NP1EO in atmospheric samples from the North Sea. Rudel et al. (2010) investigated the concentration of NP and NPE in indoor and outdoor air samples from California. The indoor $\mathrm{NP}$ concentration ranged from < LOQ to $89 \mathrm{ng} / \mathrm{m}^{3}$ and was

\section{EMISSION}

DISTRIBUTION

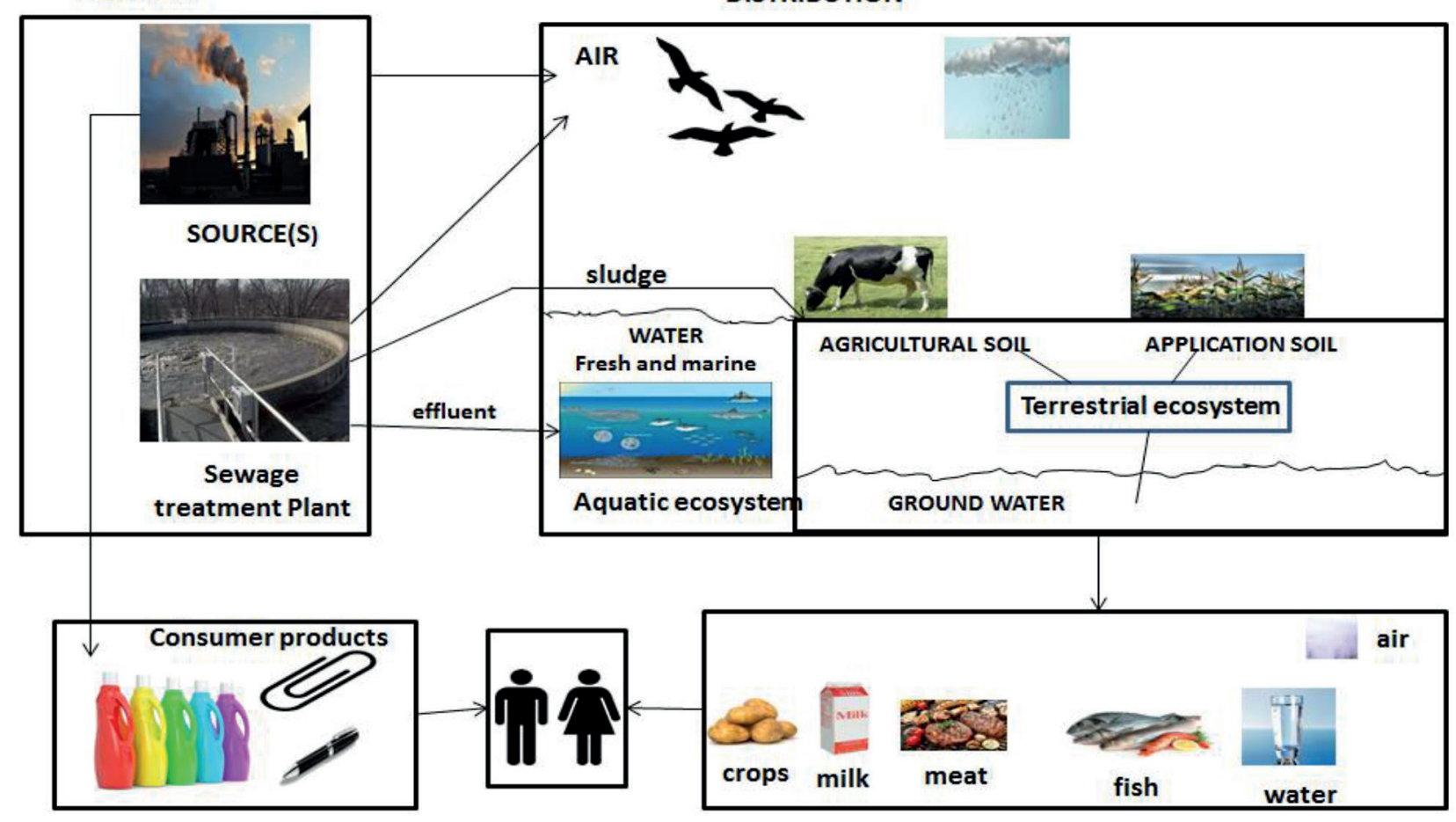

CONSUMER EXPOSURE

EXPOSURE via ENVIRONMENT

Figure 4

Schematic diagram showing the emission, distribution and exposure pathway of APES (WHO, 2004) 
higher than that outdoors $\left(<\mathrm{LOQ}\right.$ to $\left.40 \mathrm{ng} / \mathrm{m}^{3}\right)$; while indoor NPE1 concentration ranged from $<$ LOQ $-72 \mathrm{ng} / \mathrm{m}^{3}$ and was not detected in outdoor samples. Salapasidou et al. (2011) reported a concentration range of $1.6-16.5$ and $0.3-12.8 \mathrm{ng} / \mathrm{m}^{3}$ for NP and NP1EO in the atmosphere of an urban area of Thessaloniki, Greece.

\section{Wastewater}

Although they are highly treatable in well-functioning sewage treatment works, APEs and their degradation products (NP, OP, and NPE1-3) have been detected in effluents of many municipal wastewater treatment plants (WWTPs). Table 1 present some of the reported data on the levels of APs and APEs in WWTPs around the world.

The reported concentrations of APs and APEs in sewage effluents varied widely among various WWTPs, from ND-15.3 $\mu \mathrm{g} / \mathrm{L}$. The highest concentration of NP $(9.83 \mu \mathrm{g} / \mathrm{L})$ was detected in effluent samples collected in Cape Town, South Africa (Olujimi et al., 2013) while the lowest concentration $(0.028 \mu \mathrm{g} / \mathrm{L})$ was detected in the UK (Koh et al., 2008). NP was not detected from effluent samples collected in Vereeniging, South Africa (Chokwe et al., 2012), but in the same study quantifiable concentrations of nonylphenol ethoxylates (NPE1, NPE2 and NPPE) were reported. In one of the few studies that determined NPE1 and nonylphenol di-ethoxylates (NPE2), samples from Taiwan (Ding and Tzing, 1998) exhibited the highest concentration $(9.6 \mu \mathrm{g} / \mathrm{L}$ and $15.3 \mu \mathrm{g} / \mathrm{L}$; respectively) with South Africa (Chokwe et al., 2012) reporting the lowest concentrations $(2.09 \mu \mathrm{g} / \mathrm{L}$ and $0.55 \mu \mathrm{g} / \mathrm{L}$; respectively). Both the nonylphenol penta-ethoxylates (NPPE) and octylphenol penta-ethoxylates (OPPE) were detected in effluents from South Africa (Chokwe et al., 2012).

\section{Surface water}

Investigations of nonylphenol in surface waters are in agreement that its occurrence is mainly correlated with anthropogenic activities, especially for urban river sediments. The main source of NP appears to be closely related to effluent discharges from WWTPs, proximity of industrial/urban areas and other related activities such as stormwater discharge and runoff (Hale et al., 2000; Petrovic et al., 2002; Corsi et al., 2003; Micic and Hofmann, 2009). The results for NP in surface waters are presented in Table 2.

Nonylphenol concentrations in surface water ranged from ND-30 $\mu \mathrm{g} / \mathrm{L}$. The highest concentration $(30 \mu \mathrm{g} / \mathrm{L})$ was reported by Azevedo et al. (2001) from Portugal followed by $9.35 \mu \mathrm{g} / \mathrm{L}$ reported by Sibali et al. (2010) from South Africa. For nonylphenol mono-ethoxylates, the highest concentration $(5.1 \mu \mathrm{g} / \mathrm{L})$ was reported from Cuyahoga River, USA (Rice et al., 2003). Concentrations ranging between 0.1 and $7.01 \mu \mathrm{g} / \mathrm{L}$ were reported for nonylphenol penta-ethoxylates (NPPE) from the Vaal River, South Africa (Chokwe, 2015). For the octylphenol ethoxylates, a study by Sibali et al. (2010) reported a concentration range from $0.31-6.01 \mu \mathrm{g} / \mathrm{L}$ for OPPE (1-3) from the Jukskei River, South Africa. Freshwater invertebrates and fish are sensitive to this category of chemicals and have demonstrated toxicity to it in varying degrees. A chronic water quality criteria concentration for NP on freshwater species of $6.6 \mu \mathrm{g} / \mathrm{L}$ has been derived by the USEPA's Office of Water (USEPA, 2005) while a no-observable-effects concentration (NOEC) of $0.33 \mu \mathrm{g} / \mathrm{L}$ was derived in the EU risk assessment report (WHO, 2004). Some of the measured surface water concentrations exceeded both the water quality criteria for freshwater species living in the water column as well as the NOEC limit.

\section{Sediments}

Sediments are the ultimate sink or reservoir for environmentally persistent and hydrophobic organic pollutants in the aquatic environment derived from various human activities. Thus, globally, nonylphenol was found in higher concentrations in river or lake sediments than dissolved in the aqueous phase (Soares et al., 2008; Brix et al., 2010). The distribution of contaminants in the sediment of a river is also related to sediment properties such as organic carbon and particle size distribution (Baker et al., 1991; Lai et al., 2000). Nonylphenol was found to be resistant to biodegradation

TABLE 1

Concentration of APs and APEs in effluents of WWTPs

\begin{tabular}{|l|c|c|c|c|c|l|}
\hline \multirow{2}{*}{ Location } & \multicolumn{5}{|c|}{ Concentration $(\mu \mathrm{g} / \mathbf{L})$} & \multirow{2}{*}{ Reference } \\
\cline { 2 - 6 } & NP & NPE1 & NPE2 & NPPE & OPPE & \\
\hline Taiwan & 1.6 & 9.6 & 15.3 & & & Ding and Tzing, 1998 \\
\hline Switzerland & $1-6.8$ & & & & & Espejo et al., 2002 \\
\hline Spain & 0.085 & & & & & Petrovic et al., 2003 \\
\hline USA & 1.93 & 2.95 & 13.24 & $11.99^{\text {a }}$ & & Esperanza et al., 2004 \\
\hline Norway & $0.05-1.31$ & & & & & Johnson et al., 2005 \\
\hline Japan & $0.5-1.1$ & & & & & Nakada et al., 2006 \\
\hline UK & 0.028 & & & & & Koh et al., 2008 \\
\hline Greece & $0.03-0.90$ & $0.34-6.89$ & $0.41-17.4$ & & & Stasinakis et al., 2008 \\
\hline Australia & 1.627 & 2.212 & & & & Ying et al., 2008 \\
\hline South Africa & ND & 2.092 & 0.55 & $0.972^{\text {b }}$ & 1.46 & Chokwe et al., 2012 \\
\hline South Africa & $0.52-9.83$ & & & & & Olujimi et al., 2013 \\
\hline Hong Kong & $0.44-1.56$ & & & & & Xu et al., 2014 \\
\hline
\end{tabular}


in lake water/sediment systems, showing only a slight (9\%) loss (after 56 days) and 4.2\% loss (after 28 days) (Lalah et al., 2003). The degradation half-life of nonylphenolic compounds was estimated to be greater than 60 years once they enter the sediments (Shang et al., 1999). The levels of NP, OP, OPPEs and NPEs in sediments are presented in Table 3.

Adsorption processes controlling the partition of nonylphenol ethoxylates to sediments demonstrated that the organic content of the sediments was one of the most important determinants of the adsorption process, especially for short-chain nonylphenol ethoxylates (John et al., 2000). Higher concentrations of nonylphenol and its ethoxylates were detected in samples from developed countries as compared to samples from developing countries. Nonylphenol concentrations of up to $1364 \mathrm{ng} / \mathrm{g}$ were reported in sediments collected in Germany (Grund et al., 2011). A study by Verslycke et al. (2005) reported a total concentration of up $1151 \mathrm{ng} / \mathrm{g}$ for longer chain length NPEs (NPE3-16) from The Netherlands. Another study in the USA detected higher concentrations (1 800-11 $000 \mathrm{ng} / \mathrm{g}$ ) for NPE0-14 (Loyo-Rosales et al., 2007). The presence of long-chain NPEs in sediment corroborates findings by Shang et al. (1999) that little degradation of NPEs occurs once these compounds enter the sediment. Sibali et al. (2010) reported a concentration range of 1.94-941 ng/g for OPPE (1-3) in sediments from the Jukskei River, South Africa. Recently, concentration ranges of ND-46; 6.4-51; 13-82 and 24-38 ng/g for OPPE, NPE1, NPE2 and NPPE, respectively, were reported for Vaal River sediments (Chokwe et al., 2016). These results indicate that APs and APEs are ubiquitous in the environment. An NP predicted-no-effect concentration (PNEC) for sediment of $39 \mathrm{ng} / \mathrm{g}$ was derived in the EU risk assessment report using the portioning methods (WHO, 2004).

\begin{tabular}{|c|c|c|c|c|c|c|c|}
\hline \multicolumn{8}{|c|}{$\begin{array}{c}\text { TABLE } 2 \\
\text { Concentrations of APs and APEs in surface waters }\end{array}$} \\
\hline \multirow{2}{*}{ Location } & \multicolumn{6}{|c|}{ Concentration $(\mu \mathrm{g} / \mathrm{L})$} & \multirow{2}{*}{ Reference } \\
\hline & $\mathrm{NP}$ & NPE1 & NPE2 & NPPE & OP & OPPE & \\
\hline Canada & ND & & & & 0.048 & & Cathum and Sabik, 2001 \\
\hline Portugal & $0.3-30$ & & & & & & Azevedo et al., 2001 \\
\hline USA & 1.1 & 2.01 & & & & & Kannan et al., 2003 \\
\hline USA & & $0.13-5.1$ & & & & $0.0053-0.19$ & Rice et al., 2003 \\
\hline Japan & 1.6 & 0.48 & 0.56 & & & & Hoai et al., 2003 \\
\hline Korea & $0.023-0.19$ & & & & & & Li et al., 2004 \\
\hline Hong Kong & $0.029-2.59$ & & & & $0.011-0.35$ & & Li et al., 2007 \\
\hline China & $0.075-1.52$ & & & & $0.021-0.063$ & & Zhang et al., 2009 \\
\hline South Africa & $0.38-9.35$ & & & & & $0.31-6.01^{\mathrm{a}}$ & Sibali et al., 2010 \\
\hline Nigeria & $0.044-0.079$ & & & & $0.06-0.07$ & & Oketola and Fagbemigun, 2013 \\
\hline China & $0.036-3.105$ & & & & $0.0028-0.542$ & & Chen et al., 2014 \\
\hline South Africa & $0.06-0.11$ & ND-0.73 & ND-0.74 & $0.1-7.01$ & & $\mathrm{ND}-1.93^{\mathrm{b}}$ & Chokwe, 2015 \\
\hline
\end{tabular}

${ }^{a}$ Sum of OPE1, OPE2, OPE3

${ }^{b} \mathrm{OPE} 5$

\begin{tabular}{|c|c|c|c|c|c|c|c|}
\hline \multicolumn{8}{|c|}{$\begin{array}{c}\text { TABLE } 3 \\
\text { APs and APEs levels in sediment samples }\end{array}$} \\
\hline \multirow{2}{*}{ Location } & \multicolumn{6}{|c|}{ Concentration (ng/g) } & \multirow{2}{*}{ Reference } \\
\hline & NP & NPE1 & NPE2 & NPPE & OP & OPPE & \\
\hline USA & $75-340$ & $32-320$ & $30-200$ & $54-159$ & & 74 & Rice et al., 2003 \\
\hline USA & $5.8-15.3$ & & & & & & Kannan et al., 2003 \\
\hline Korea & $25.4-932$ & & & & & & Li et al., 2004 \\
\hline The Netherlands & ND-1 222 & ND-51.9 & ND-221 & ND-1 151 ${ }^{\mathrm{a}}$ & & & Verslycke et al., 2005 \\
\hline Spain & $13-225$ & & & & & & Lara-Martin et al., 2006 \\
\hline Italy & $47-192$ & & & & & & Pojana et al., 2007 \\
\hline USA & & & & $1800-11000^{\mathrm{b}}$ & & & Loyo-Rosales et al., 2007 \\
\hline Brazil & $1-10$ & & & & & & Fiedler et al., 2007 \\
\hline South Africa & & & & & & $1.94-941^{\mathrm{c}}$ & Sibali et al., 2010 \\
\hline Germany & ND-1 364 & & & & & & Grund et al., 2011 \\
\hline China & $16.6-203.8$ & & & & ND-2.6 & & Wang et al., 2012 \\
\hline Nigeria & $1.1-79.4$ & & & & $2.2-24.5$ & & Oketola and Fagbemigun, 2013 \\
\hline Poland & $1.46-2.31$ & & & & $6.56-13.1$ & & Koniecko et al., 2014 \\
\hline South Africa & ND & $6.4-51$ & $13-82$ & $24-38$ & $\mathrm{ND}-46$ & & Chokwe et al., 2016 \\
\hline
\end{tabular}

${ }^{a}$ Sum of NPE3-16

${ }^{b}$ Sum of NPE0-14

'Sum of OPE1-3 


\section{Biota}

Alkylphenols are lipophilic and thus accumulate in fatty tissues (Vazquez-Duhalt et al., 2005; Uguz et al., 2003; Abdulla Bin-Dohaish, 2012). Uptake occurs mainly through two pathways: water (gill ventilation) and diet. Generally, high concentrations of APEs are expected to be found in the liver relative to muscle because of the liver's role in storage, detoxification and regulation of all metabolic process (Uguz et al., 2003). However, most of the analysed publications limited their studies to APE levels in muscle and this will therefore be discussed in this section.

Fish, mussel and shellfish are the most common biosamples because they are typical aquatic organisms that might be sensitive to APs and APEs in surface water. The ability of these organisms to accumulate APs and APEs depends on their feeding strategy (David et al., 2009). A higher portion of APEs and APs were detected in organisms with higher exposure to sediments, suggesting that the main source of APEs and APs may not be the water column, but sediments and dietary uptake, both depending on their distribution in the aquatic environment (Ferreira-Leach and Hill, 2001; David et al., 2009).

NP, NPE1 and NPE2 were detected in all shellfish samples obtained from rivers flowing into Lake Biwa, Japan with concentration ranges of $2.8-19.3,7.7-23.3,2.0-5.3 \mathrm{ng} / \mathrm{g}$ wet wt., respectively (Tsuda et al., 2002). Datta et al. (2002) reported the concentration of NP and NPEs in trout, common carp and yellow perch from various locations in the USA Great Lakes region. Concentrations of NP, NPE1, NPE2, and NPE3 from fish samples ranged from 18-2 $075 \mathrm{ng} / \mathrm{g}$ wet weight. In the Cuyahoga River, USA the concentration of NPE0-2 in carp ranged from 32-920 ng/g (Rice et al., 2003). A concentration range of 151-300 ng/g for NP was reported in 6 fishes (i.e., weever, catfish, bartail flathead, white flower croaker, wolfish, and mullet) from Bohai Bay by Hu et al. (2005). Wang et al. (2007) reported NP in mussels from the Masan Bay of Korea, where concentrations ranged from 50.5-289.2 ng/g dry wt. In the Venice lagoon, NP in mussels was detected with a concentration range of 115-211 ng/g dry wt (Pojana et al., 2007). Concentrations ranging from 32.6$47.2 \mathrm{ng} / \mathrm{g}$ were detected in carp and moggel (Labeo umbratus) from South Africa (Chokwe et al., 2015b).

\section{Sludge}

Sorption to sludge, as a consequence of a high affinity for organic matter, and biological degradation are major removal mechanisms for APEs during wastewater treatment (Scrimshaw and Lester, 2002; Shao et al., 2003; Soares et al., 2008; Stasinakis et al., 2008). It has also been reported that treatment plants that treat wastewater of industrial origin, or from areas with high population densities indicative of an urban area, exhibit high concentration of APEs (Langford and Lester, 2002). Few studies have been reported the presence of APEs in sludge. La Guardia et al. (2001) investigated concentrations of APE degradation products (NP, NPE1, NPE2) in sludge from 11 US WWTPs and found that concentrations were highest in the anaerobically digested samples (721 000-981 $000 \mathrm{ng} / \mathrm{g}$ dry wt). In the majority of samples, NP was the most abundant. NP concentrations of $242000 \mathrm{ng} / \mathrm{g}$ (sludge before anaerobic digestion) and $308000 \mathrm{ng} / \mathrm{g}$ (sludge anaerobically stabilized) were reported by Bruno et al. (2002) in a sludge sample from Italy. Concentrations ranging from 3 600-93 $000 \mathrm{ng} / \mathrm{g}$ and $12800-233500 \mathrm{ng} / \mathrm{g}$ for NP and NPEO, respectively, were reported by Fountoulakis et al. (2005) in three WWTPs (Athens, Patras and Heraklion) in Greece. NP, NPE1 and NPE2 concentrations (110, 1010 and $2890 \mathrm{ng} / \mathrm{g}$, respectively) were reported by Gatidou et al. (2007) from Mytilene City WWTPs, Greece. In Spain, the concentrations of NP, NPE1 and NPE2 were determined from biological wastewater treatment plants and ranges from $3200-$ 199000 ng/g were reported (Fernández-Sanjuan et al., 2009). A concentration range of between ND and $642 \mathrm{ng} / \mathrm{g}$ was reported by Chokwe et al. (2015c) for sludge samples from three WWTPs in South Africa.

\section{EXPOSURE PATHWAYS TO APES}

According to human exposure assessments, as shown in Fig. 4, non-occupational exposure to APEs can occur through a variety of exposure pathways including inhalation of air, ingestion of food and indoor dust, and by drinking contaminated water (Ying et al., 2002; Erickson, 2002; Lu et al., 2007; Salapasidou et al., 2011; Zhou et al., 2011). Another source of exposure might be via the cleaning agents used in the food-processing industry, or plastic packaging materials from which NP, used in tris(nonylphenol) phosphite as an oxidant, could migrate into food (Inoue et al., 2001; LoyoRosales et al., 2004). When animals ingest NP, its absorption from the gastrointestinal tract is initially rapid, and probably extensive. NP is distributed widely throughout the body, with the highest concentrations in fatty tissues (WHO, 2004).

\section{Exposure through food}

NP levels were measured in 39 foods and beverages, including fruits and vegetables, dairy products, fish and meat, pasta, beer, coffee and chocolate, from German supermarkets, by Güenther et al. (2002), who found a concentration range of $0.1-19.4 \mu \mathrm{g} / \mathrm{kg}$. These findings suggest that food may be an important route of exposure to endocrine-disrupting compounds (EDCs) like APEs in humans. A similar study was conducted by Lu et al. (2007) in Taiwan by sampling 25 types of food consumed by locals, including two freshwater fish, two saltwater fish, two shellfish, two other seafoods, poultry, livestock, vegetables, rice and noodles, three other proteins and fruits. The foodstuff samples were analysed for NP, OP, butylphenol (BP), NPE1 and NPE2. NP was detected in 243 samples from the total of 318 samples (76.4\%), with an average concentration of $235.8 \pm 90.7 \mu \mathrm{g} / \mathrm{kg}$. NP in vegetables can likely be attributed to pesticides (Güenther et al, 2002). Both branched and linear NP were detected in the tissues of pumpkin, carrot, and citrus purchased from Florida, with the highest concentration, of $18.5 \mu \mathrm{g} / \mathrm{kg}$, reported for citrus ( $\mathrm{Lu}$ et al., 2013). NP concentration ranged from 1.18 to $4.31 \mu \mathrm{g} / \mathrm{kg}$ (lettuce) and 3.79 to $6.95 \mu \mathrm{g} / \mathrm{kg}$ (collard) in the stems and leaves while the concentrations in the roots of lettuce and collard were $926.9 \mu \mathrm{g} / \mathrm{kg}$ and $339.2 \mu \mathrm{g} / \mathrm{kg}$, respectively (Dodgen et al, 2013). Monitoring studies by Dodder et al. (2014) reported NP levels exceeding $50 \mu \mathrm{g} / \mathrm{kg}$ and a detection frequency of more than $50 \%$ in mussel tissues collected along the Californian coast. The data supported the trend that NP levels increase with increasing urbanization of the sampling site (Careghini et al., 2014; Luo et al., 2014). 


\section{Exposure through air and other pathways}

Exposures to APEs are not always exclusively through food. Other exposure pathways to these compounds may include non-dietary ingestion, dermal absorption from product use, drinking contaminated water and inhalation (Rudel and Perovich, 2009). A day-care study concluded that dietary ingestion was the primary exposure pathway for toddlers to a group of phenolic compounds that included nonylphenol, though inhalation was found to be a secondary route of exposure (Wilson et al., 2001). Short-chain alkylphenol polyethoxylates have been found in drinking water and groundwater in the US (White et al., 1994; Rudel et al., 1998; Swartz et al., 2006) indicating that drinking of contaminated water is another exposure pathway to NP.

\section{TOXICITY}

Exposure to APE degradation products can result in acute and/or chronic toxicity to aquatic organisms (Langston et al., 2005; Vazquez-Duhalt et al., 2005). Studies have demonstrated that APEs compete for the binding site of natural oestrogen receptors in vertebrates and can elicit a variety of responses, including stimulation of vitellogenin, an egg-yolk protein in males; modification of testicular structure and decreased sperm counts thus leading to both intersex fish and altered sex ratios in populations, and induction of both liver damage and mortality (Servos, 1999; Ackermann et al, 2002; Bakke, 2003; Staples et al., 2004; Rempel and Schlenk, 2008; Amaro et al., 2014; Chen et al., 2014). Among marine organisms, gastropods and bivalves appear to be most sensitive to the effects of NP and OP, followed by fish, other invertebrates and then algae (Staples et al., 2004; Van Miller and Staples, 2005; Wang et al., 2010; Gao et al., 2014; Hsu et al., 2016). In general, decreasing exothylate chain length has been correlated with increasing toxicity (Servos et al., 2003). Chronic toxicity values and no-observed-effect concentrations (NOEC) are as low as $6 \mu \mathrm{g} / \mathrm{L}$ in fish and $3.7 \mu \mathrm{g} / \mathrm{L}$ in invertebrates, respectively (Servos, 1999). Lowestobserved-effect concentration (LOEC) was at a nominal dose of $4 \mu \mathrm{g} / \mathrm{kg}$ body weight of AP for effects on the timing of puberty, while the delay effect in mature fish was at $20 \mu \mathrm{g} /$ $\mathrm{kg}$ body weight (Meier et al., 2011). A study by Bellingham et al. (2010) demonstrated that the developing foetus during pregnancy was sensitive to environmentally relevant concentrations of EDCs that may have a serious impact on the future development of the reproductive system. Xie et al. (2013) showed that nonylphenol and tert-octylphenol bind with human serum albumin during transport and metabolic processes in vitro. The USEPA guideline for ambient water quality designates nonylphenol concentrations of below $6.6 \mu \mathrm{g} / \mathrm{L}$ and $1.7 \mu \mathrm{g} / \mathrm{L}$ in freshwater and saltwater, respectively (USEPA, 2005; Brooke and Thursby, 2005). In the European Union (EU) risk assessment report on NP of 2001 a no-observable-effect concentration (NOEC) of $0.33 \mu \mathrm{g} / \mathrm{L}$ was derived (WHO, 2004).

\section{MAJOR KNOWLEDGE GAPS FOR ALKYLPHENOL ETHOXYLATES}

Wastewater effluents were identified as a major source of APEs and their degradation by-products in the environment; thus, more studies should be undertaken to measure the levels of APEs at WWTP outfalls, and terrestrial environments close to agricultural, mining and chemical industries, as the concentration are expected to be highest there. Within effluent studies, as these pollutants are directly linked to urbanization (Falconer et al., 2006), the impact of population increases in metropolitan areas need to be assessed for APEs pollution. As sewage is known to be released into wetlands and oceanic waters, studies of APE levels in these compartments' inhabitants (such as birds, frogs, algae, daphnia, dolphins, etc.) need to be undertaken in order to assess the impact of APEs on biodiversity of such bodies. Indoor dust has been implicated as an important exposure route for other persistent organic pollutants (POPs) such as TBBPA (Abdallah et al., 2008; Harrad et al., 2010), PBDEs (Ali et al., 2013; Abafe and Martincigh, 2015) and PCBs (Abafe and Martincigh, 2015); an accurate assessment (occurrence and fate) of alkylphenol ethoxylates in the indoor environment is of major importance for developing countries as the use of these endocrine-disrupting chemicals is suspected to be on the rise.

There were two studies considered in this review which reported on degradation of NPE0-16 (Verslycke et al., 2005; Loyo-Rosales et al., 2007). Though these studies confirmed $\mathrm{NP}$ as the major product, more information on the behaviour and degradation of the longer-chain NPE6-16 in different environmental matrices and biota becomes of utmost importance. In addition, the fate and transport of the longerchain NPE in the environment is still not well understood. Also, there is a paucity of data on the adverse health impacts of NPE1-3. Hence, studies should be undertaken to establish the minimum health risk concentration for each isomer as well as to investigate the synergic health effect of a combination of different environmentally relevant concentrations of APEs. There is a scarcity of data on human biological monitoring for APEs around the globe and more research also needs to be directed toward NPE isomer identification, as the available studies determined exposure to technical mixtures of OPs and NPs (Calafat et al., 2005; 2008; Faniband et al., 2014).

NPE (1-3) as emerging environmental contaminant should be studied systematically to evaluate their potential threat to environmental and human health. To accomplish this goal, research activities should look into, among others: (i) developing analytical methods to measure these pollutants in a variety of matrices down to trace levels; (ii) fate and transport of NP and NPE (1-3) in air; (iii) more toxicity data to assess the effects on terrestrial organisms such as plants; and (iv) potential effects on wildlife due to long-term exposure to low concentrations of NP and NPEs.

\section{CONCLUSIONS}

Irrespective of sources, APEs have become ubiquitous in the environment. The occurrence of APEs and APs has been reported around the globe in wastewater effluents, surface waters, sediments, biota and air. Discharges from WWWTPs were found to be a major source of these compounds in the environment, though atmospheric deposition, urban runoff and direct discharge, such as application of pesticides to aquatic vegetation, may also be important sources of these compounds in the environment and humans. There were few results cited in the review that showed concentrations of NP above the USEPA guideline for ambient water quality, thus indicating moderate to high risk from contamination by NP of surface waters around the globe. Exposure pathways to these compounds include: contaminated foods, ingestion, inhalation and water. 
Thus, the presence of APEs in the food chain, indoor air, dust and water should be continuously monitored. More studies are required to further understand the fate and transport of NPE $(6-16)$ in the environment and biota as well as adverse health impacts of NPE (1-3) isomers in wildlife and humans.

\section{ACKNOWLEDGEMENTS}

The authors would like to thank Rand Water Analytical Services for providing a technical environment and funding of the project and Tshwane University of Technology for support. The authors also declare there is no conflict of interest.

\section{REFERENCES}

ABAFE OA and MARTINCIGH BS (2015) Polybrominated diphenyl ethers and polychlorinated biphenyls in indoor dust in Durban, South Africa. Indoor Air 25 547-556. https://doi.org/10.1111/ ina. 12168

ABDALLAH MAE, HARRAD S and COVACI A (2008) Hexabromocyclododecanes and tetrabromobisphenol A in indoor air and dust in Birmingham, UK: implications for human exposure. Environ. Sci. Technol. 42 6855-6861. https://doi. org/10.1021/es801110a

ABDULLA BIN-DOHAISH EJ (2012) The effects of nonylphenol contamination on livers of Tilapia fish (Oreochromus spilurs) in Jeddah. Biol. Res. 45 15-20. https://doi.org/10.4067/ S0716-97602012000100002

ACEVEDO R, PARNELL P G, VILLANUEVE H, CHAPMAN L M, GIMENEZ T, GRAY SL and BALWIN WS (2005) The contribution of hepatic steroid metabolism to serum estradiol and estriol concentrations in nonylphenol treated MMTVneu mice and its potential effects on breast cancer incidence and latency. J. Appl. Toxicol. 25 339-353. https://doi.org/10.1002/jat.1078

ACKERMANN GE, SCHWAIGER J, NEGELE RD and FENT K (2002) Effects of long term nonylphenol exposure on gonadal development and biomarkers of oestrogenicity in juvenile rainbow trout (Oncorhynchus mykiss) Aquat. Toxicol. 60 203-221. https://doi. org/10.1016/S0166-445X(02)00003-6

AHEL M and GIGER W (1993) Partitioning of alkylphenols and alkylphenol polyethoxylates between water and organic solvents. Chemosphere 26 1471-1478. https://doi. org/10.1016/0045-6535(93)90214-P

ALI N, ALI L, MEHDI T, DIRTU AC, AL-SHAMMARI F, NEELS H and COVACI A (2013) Levels and profiles of organochlorines and flame retardants in car and house dust from Kuwait and Pakistan: implication for human exposure via dust ingestion. Environ. Int 55 62-70. https://doi.org/10.1016/j.envint.2013.02.001

AMARO AA, ESPOSITO AI, MIRISOLA V, MEHILLI A, ROSANO C, NOONAN DM, ALBINI A, PFEFFER U and ANGELINI G (2014) Endocrine disruptor agent nonylphenol exerts an oestrogenlike transcriptional activity on oestrogen receptor positive breast cancer cells. Curr. Med. Chem. 21 (15) 630-640. https://doi.org/10.2 174/09298673113209990169

AZEVEDO DA, LACORTE S, VIANA P and BARCELÓ D (2001) Occurrence of nonylphenol and bisphenol A in surface water from Portugal. J. Braz. Chem. Soc. 12 (4) 532-537. https://doi. org/10.1590/S0103-50532001000400015

BAKER JE, EISENREICH SJ and EADIE SJ (1991) Sediment trap fluxes and benthic recycling of organic carbon, polycyclic aromatic hydrocarbons and polychlorobiphenyl congeners in Lake Superior. Environ. Sci. Technol. 25 500-509. https://doi.org/10.1021/ es00015a019

BAKKE D (2003) Human and ecological risk assessment of nonylphenol polyethoxylates-based (NPE) surfactants in forest service herbicide application. Pacific South West Region (Region 5). USDA Forest Service. URL: http://www.fs.usda.gov/Internet/FSE_ DOCUMENTS/stelprdb5346866.pdf (Accessed 27 January 2016).

BELLINGHAM M, FOWLER PA, AMEZAGA MR, WHITELAW CM, RHIND SM, COTINOD C, MANDON-PEPIN B, SHARPE RM and EVANS NP (2010) Foetal hypothalamic and pituitary expression of gonadotrophin-releasing hormone and galanin systems is distributed by exposure to sewage sludge chemicals via maternal ingestion. J Neuroendocrinol. 22 527-533. https:// doi.org/10.1111/j.1365-2826.2010.01974.x

BJORKLAND K, PALM-COUSINS A, STRÖMCALL A and MALMQVIST P (2009) Phthalates and nonylphenols in urban runoff: occurrence, distribution and area emission factors. Sci. Tot. Environ. 407 4665-4672. https://doi.org/10.1016/j. scitotenv.2009.04.040

BONEFELD-JORGENSEN EC; LONG M; HOFMEISTER MV and VINGGAARD AM (2007) Endocrine disrupting potential of bisphenol A, bisphenol A dimethacrylate, 4-nonylphenol and 4-octylphenol in vitro: new data and brief review. Environ. Health Perspect. 115 (suppl 1) 69-76. https://doi.org/10.1289/ehp.9368

BRIX R, POSTIGO C, GONZALEZ S, VILLAGRASA M, NAVARRO A, KUSTER M, DE ALDA MJL and BARCELÓ D (2010) Analysis and occurrence of alkylphenolic compounds and oestrogens in a European river basin and evaluation of their importance as priority pollutants. Anal. Bioanal. Chem. 396 1301-1309. https://doi. org/10.1007/s00216-009-3358-8

BROOKE L and THURSBY G (2005) Ambient aquatic life water quality criteria for nonylphenol. Report to the United States EPA, Office of Water, Office of Science and Technology, Washington DC.

BRUNO F, CURINI R, DI CORCI A, FOCHI I, NAZZARI M, SAMPERI R (2002) Determination of surfactants and some of their metabolites in untreated and anaerobically digested sewage sludge by subcritical water extraction followed by liquid chromatographymass spectrometry. Environ. Sci. Technol. 364156 -4161. https:// doi.org/10.1021/es020002e

CALAFAT AM, KUKLENYIK Z, REIDY JA, CAUDILL SP, EKONG J and NEEDHAM LL (2005) Urinary concentrations of bisphenol A and 4-nonylphenol in a human reference population. Environ. Health Perspect. 113 391-395. https://doi.org/10.1289/ehp.7534

CALAFAT AM, YE X, WONG LY, REIDY JA and NEEDHAM LL (2008) Exposure of the U.S. population to bisphenol A and 4-tertiary-octylphenol: 2003-2004. Environ. Health Perspect. 116 39-44. https://doi.org/10.1289/ehp.10753

CAREGHINI A, MASTORGIO AF, SAPONARO S and SEZENNA E (2014) Bisphenol A, nonylphenols, benzophenones and benzotriazoles in soils, groundwater, surface water, sediments and food: a review. Environ. Sci. Pollut. Res. 22 (8) 5711-5741. https:// doi.org/10.1007/s11356-014-3974-5

CATHUM S and SABIK H (2001) Simultaneous determination of alkylphenol polyethoxylate surfactants and their degradation products in water, effluent and mussel using gas-chromatographymass spectrometry. Chromatographia 51 400-405. https://doi. org/10.1007/BF02490365

CHEN B, DUAN J, MAIA B, LUO X, YANG Q, SHEN G and FU J (2006) Distribution of alkylphenols in the Pearl River and adjacent northern South China Sea, China. Chemosphere 63 (4) 652-661. https://doi.org/10.1016/j.chemosphere.2005.08.004

CHEN R, YIN P, ZHAO L, YU Q, HONG A and DUAN S (2014) Spatial-temporal distribution and potential ecological risk assessment of nonylphenol and octylphenol in riverine outlets of Pearl River Delta, China. J. Environ. Sci. 26 2340-2347. https://doi. org/10.1016/j.jes.2014.09.019

CHIU TY, PATERAKIS N, CARTMELL E, SCHRIMSHAW MD and LESTER JN (2010) A critical review of the formation of monoand dicarboxylated metabolic intermediates of alkylphenol poly ethoxylates during wastewater treatment and their environmental significance. Environ. Sci. Technol. 40 199-238. https://doi. org/10.1080/10643380802219517

CHOKWE TB, OKONKWO JO, SIBALI LL and NCUBE EJ (2012) Optimization and simultaneous determination of alkylphenol ethoxylates and brominated flame retardants in water after SPE and heptafluorobutyric anhydride derivatization followed by GC/MS. Chromatographia 75 1165-1176. https://doi.org/10.1007/ s10337-012-2293-6

CHOKWE TB, OKONKWO JO, SIBALI LL and NCUBE EJ (2014) Improved derivatization protocol for simultaneous determination of alkylphenol ethoxylates and brominated flame retardants followed by gas chromatography-mass spectrometry. Water Sci. Technol. 69 2389-2396. https://doi.org/10.2166/wst.2014.144 
CHOKWE TB (2015) Alkylphenol ethoxylates and brominated flame retardants in the Vaal River: a study of pre-concentration and derivatization followed by gas chromatography- mass spectrometry. DTech thesis, Department of Water, Environmental and Earth Sciences, Tshwane University of Technology, Pretoria.

CHOKWE TB, OKONKWO JO, SIBALI LL and MPORETJI SM (2016) Occurrence and distribution pattern of alkylphenol ethoxylates and brominated flame retardants in sediment samples from Vaal River, South Africa. Bull. Environ. Contam. Toxicol. 97 353-358. https://doi.org/10.1007/s00128-016-1886-4

CHOKWE TB, OKONKWO JO, SIBALI LL and NCUBE EJ (2015a) Alkylphenol ethoxylates and brominated flame retardants in water, carp and sediment samples from Vaal River, South Africa. Environ. Sci. Pollut. Res. 22 11922-11929. https://doi.org/10.1007/ s11356-015-4430-X

CHOKWE TB, OKONKWO OJ, SIBALI LL, KRÜGER E, DU PREEZ H, HARIRAM R and NCUBE EJ (2015b) A simplified analytical procedure for simultaneous determination of alkylphenol ethoxylates and brominated flame retardants in fish tissue samples from Vaal River, South Africa. Am. J. Anal. Chem. 6 422-428. https://doi.org/10.4236/ajac.2015.65041

CHOKWE TB, OKONKWO OJ, SIBALI LL and NCUBE EJ (2015c) An integrated method for the simultaneous determination of alkylphenol ethoxylates and brominated flame retardants in sewage sludge samples by ultrasonic-assisted extraction, solid phase clean-up, and GC-MS analysis. Microchem. J. 123 230-236. https:// doi.org/10.1016/j.microc.2015.07.001

CORSI SR, ZITOMER DH, FIELD JA and CANCILLA DA (2003) Nonylphenol ethoxylates and other additives in aircraft de-icers, anti-icers, and water receiving airport runoff. Environ. Sci. Technol. 37 4031-4037. https://doi.org/10.1021/es034005i

DACHS J, VAN RY DA and EISENREICH SJ (1999) Occurrence of oestrogenic nonylphenols in the urban and coastal atmosphere of the lower Hudson River estuary. Environ. Sci. Technol. 33 26762679. https://doi.org/10.1021/es034005i

DATTA S, LOYO-ROSALES JE and RICE CP (2002) A simple method for the determination of trace levels of alkylphenolic compounds in fish tissue using pressurized fluid extraction, solid phase clean-up, and high performance liquid chromatography fluorescence detection. J Agric. Food Chem. 50 1350-1354. https:// doi.org/10.1021/jf0111357

DAVID A, FENET H and GOMEZ E (2009) Alkylphenols in marine environments: distribution monitoring strategies and detection considerations. Mar. Pollut. Bull. 58 953-960. https://doi. org/10.1016/j.marpolbul.2009.04.021

DE VOOGT P, DE BEER K and VAN DER WIELEN F (1997) determination of alkylphenol ethoxylates in industrial and environmental samples. Trends Anal. Chem. 16 (10) 584-595. https://doi.org/10.1016/S0165-9936(97)00100-3

DIAZ A, VENTURA F and GALCERAN MT (2002) Simultaneous determination of oestrogenic short-ethoxy-chain nonylphenols and their acidic metabolites in water by an in-sample derivatization/ solid phase micro-extraction method. Anal. Chem. 74 3869-3876. https://doi.org/10.1021/ac020124p

DIEHL J, JOHNSON SE, XIA K, WEST A and TOMANEK L (2012) The distribution of 4-nonylphenol in marine organism of North American Pacific Coast estuaries. Chemosphere 87 (5) 490-497. https://doi.org/10.1016/j.chemosphere.2011.12.040

DING WH and TZING SH (1998) Analysis of nonylphenol polyethoxylates and their degradation products in river and sewage effluent by gas chromatography-ion trap (tandem) mass spectrometry with electron impact and chemical ionization. J. Chromatogr. A 824 79-90. https://doi.org/10.1016/ S0021-9673(98)00593-7

DIRECTIVE 2000/60/EC (2000) Establishment and framework for community action in the field of water policy. European Parliament and the Council of the European Union, Luxembourg.

DIRECTIVE 2003/53/EC (2003) Amending for the $26^{\text {th }}$ time the Council directive 76/769/EEC relating to restrictions on the marketing and use of certain dangerous substances and preparations (nonylphenol, nonylphenol ethoxylates and cement). European Parliament and the Council of the European Union, Luxembourg.
DODDER LK, MARUYA KA, LEE- FERGUSON P, GRACE R, KLOSTERHAUS S, LA GUARDIA MJ, LAUENSTEIN GG and RAMIREZ J (2014) Occurrence of contaminants of emerging concern in mussels (Mytilus spp.) along the California coast and influence of land use, storm water discharge and treated wastewater effluent. Mar. Pollut. Bull. 81 340-346. https://doi.org/10.1016/j. marpolbul.2013.06.041

DODGEN LK, LI J, PARKER D and GAN JJ (2013) Uptake and accumulation of four PPCP/ EDCs in two leafy vegetables. Environ. Pollut. 182 150-156. https://doi.org/10.1016/j.envpol.2013.06.038

ERICKSON B (2002) Endocrine disrupting nonylphenols detected in wide range of foods. Environ. Sci. Technol. 36 (9) 178-179. https:// doi.org/10.1021/es0222925

ESPEJO R, VALTER K, SIMONA M, JANIN Y and ARRIZABALGA $P$ (2002) Determination of nineteen 4-alkylphenol endocrine disrupters in Geneva municipal sewage wastewater. J. Chromatogr. A 979 335-343. https://doi.org/10.1016/S0021-9673(02)01229-3

ESPERANZA M. SUIDAN MT, NISHIMURA F, WANG ZM, SORIAL GA, ZAFFIRO A, MCCAULEY P, BRENNER R and SAYLES G (2004) Determination of sex hormones and nonylphenol ethoxylates in the aqueous matrixes of two pilot-scale municipal wastewater treatment plants. Environ. Sci. Technol. 38 3028-3035. https://doi.org/10.1021/es0350886

FALCONER IR, CHAPMAN HF, MOORE MR, and RANMUTHUGALA G (2006) Endocrine disrupting compounds: A review of their challenge to sustainable and safe water reuse. Environ. Toxicol. 21 181- 191. https://doi.org/10.1002/tox.20172

FANIBAND M, LINDH CL and JÖNSSON BO AG (2014) Human biological monitoring of suspected endocrine disrupting compounds. Asian J. Androl. 16 5-16. https://doi. org/10.4103/1008-682X.122197

FARRE M, KLOTER G, PETROVIC M, ALONSO MC, DE ALDA MJL and BARCELÓ D (2002) Identification of toxic compounds in wastewater treatment plants during a field experiment. Anal. Chim. Acta 456 19-30. https://doi.org/10.1016/S0003-2670(01)00908-4

FERNÁNDEZ- SANJUAN M, RIGOL A, SAHUQUILLO A, RODRÍGUEZ-CRUZ S, LACORTE S (2009) Determination of alkylphenols and alkylphenol ethoxylates in sewage sludge: effect of sample treatment. Anal. Bional. Chem. 394 1525-1533. https://doi. org/10.1007/s00216-009-2747-3

FERREIRA-LEACH AMR and HILL EM (2001) Bioconcentration and distribution of 4-tert-octylphenol residues in tissues of the rainbow trout (Oncorhynchus mykiss). Mar. Environ. Res. 51 75-89. https:// doi.org/10.1016/S0141-1136(00)00256-7

FIEDLER S, FOERSTER M, GLASER B and ZECH W (2007) Alkylphenols in sediments of the Atlantic Rainforest southwest of São Paulo, Brazil. Chemosphere 66 212-218. https://doi. org/10.1016/j.chemosphere.2006.05.064

FOUNTOULAKIS M, DRILLIA P, PAKOU C, KAMPOTIOTI A, STAMATELATOU K and LYBERATOS G (2005) Analysis of nonylphenol and nonylphenol ethoxylates in sewage sludge by high performance liquid chromatography following microwave-assisted extraction, J. Chromatogr. A 1089 45-51. https://doi.org/10.1016/j. chroma.2005.05.109

FRIES E and PUTTMANN W (2004) Occurrence of nonylphenol in rain and snow. Atmos. Environ. 38 2013-2016. https://doi. org/10.1016/j.atmosenv.2004.01.013

FUJITA M, IKE M, MOI K, KAKU H, SAKAGUCHI Y and ASANO M (2000) Behaviour of nonyl phenol ethoxylates in sewage treatment plants in Japan: biotransformation and ecotoxicity. Water Sci. Technol. 42 23-30.

GAO P, LI Z, GIBSON M and GAO H (2014) Ecological risk assessment of nonylphenol in coastal waters of China based on species sensitivity distribution model. Chemosphere 104 113-119. https:// doi.org/10.1016/j.chemosphere.2013.10.076

GATIDOU G, THOMAIDIS NS, STASINAKIS AS and LEKKAS TD (2007) Simultaneous determination of the endocrine disrupting compounds nonylphenol, nonylphenol ethoxylates, triclosan and bisphenol $\mathrm{A}$ in wastewater and sewage sludge by gas chromatography-mass spectrometry. J. Chromatogr. A $113832-41$. https://doi.org/10.1016/j.chroma.2006.10.037

GIBBLE R and BAER KN (2003) Effects of 4-nonylphenol on sexual maturation in daphnia magna. Bull. Environ. Contam. Toxicol. 
70 315-321. https://doi.org/10.1007/s00128-002-0193-4

GIGER W, BRUNNER PH and SCHAFFNER C (1984) 4-nonylphenol in sewage sludge: accumulation of toxic metabolites from nonionic surfactants. Science 225 623-625. https://doi.org/10.1126/ science.6740328

GILART N, BORRULL F, FONTANALS N and MARCÉ RM (2014) Selective materials for solid-phase extraction in environmental analysis. Trends Environ. Anal. Chem. 1 8-18. https://doi. org/10.1016/j.teac.2013.11.002

GLASSMEYER ST, FURLONG ET, KOLPIN DW, CAHILL JD, ZUAGG SD, WERNER SL, MEYER MT and KRYAK DD (2005) Transport of chemical and microbial compounds from known wastewater discharges: potential for use as indicators of human fecal contamination. Environ. Sci. Technol. 39 5157-5169. https:// doi.org/10.1021/es048120k

GONG J, XU L, YANG Y, CHEN Y and RAN Y (2011) Sequential ASE extraction of alkylphenols from sediments: occurrence and environmental implications. J. Hazardous Mater. 192 (2) 643-650. https://doi.org/10.1016/j.jhazmat.2011.05.071

GRUND S, SCHOENENBERGER R, SUTER MJF and GIESY JP (2011) The endocrine disrupting potential of sediments from the upper Dunabe River (Germany) as revealed by in vitro bioassays and chemical analysis. Environ. Sci. Technol. 18 446-460.

GÜENTHER K, HEINKE V, THIELE B, KLEIST E, PRAST H and RAECKER T (2002) Endocrine disrupting nonylphenols are ubiquitous in food. Environ. Sci. Technol. 36 1676-1680. https://doi. $\operatorname{org} / 10.1021 /$ es $010199 \mathrm{~V}$

GÜENTHER K, KLEIST E and THIELE B (2006) Oestrogen-active nonylphenols from an isomer specific viewpoint: a systematic numbering system and future trends. Anal. Bioanal. Chem. 384 (2) 542-546. https://doi.org/10.1007/s00216-005-0181-8

GURUGE KS, HORII Y and YAMASHITA N (2011) Profiles of nonylphenol isomers in surface waters from Sri Lanka. Mar. Pollut. Bull. 62 (2) 870-873. https://doi.org/10.1016/j. marpolbul.2011.01.024

HALE RC, SMITH CL, DE FUR PO, HARVEY E and BUSH EO (2000) Nonylphenols in sediments and effluents associated with diverse wastewater system outfalls. Environ. Toxicol. Chem. 19946-952. https://doi.org/10.1002/etc.5620190423

HARRADS, GOOSEY E, DESBOROUGH J, ABDALLAH MAE, ROOSENS L and COVACI A (2010) Dust from U.K. primary school classrooms and daycare centers: the significance of dust as a pathway of exposure of young U.K. children to brominated flame retardants and polychlorinated biphenyls. Environ. Sci. Technol. 44 4198-4202. https://doi.org/10.1021/es100750s

HEALTH CANADA (2001) Priority substances list assessment report. Nonylphenol and nonylphenol ethoxylates. April 2001. URL: http:// www.hc-sc.gc.ca/ewh-semt/pubs/contaminants/ps12-880 lsp2/ nonylphenol/index-eng.php (Accessed 12 August 2016).

HOAI PM, TSUNOI S, IKE M, KURATANI Y, KUDOU K, VIET PH, FUJITA M and TANAKA M (2003) Simultaneous determination of degradation products of nonylphenol ethoxylates and their halogenated derivatives by solid phase extraction and gas-chromatography-tandem mass spectrometry after trimethylsilylation. J. Chromatogr. A 1020 161-171. https://doi. org/10.1016/j.chroma.2003.08.064

HSU TH, CHEN CY and GWO JC (2016) Causes of the skewed sex ratio in the critically endangered Formosa landlocked salmon of Taiwan. Endang. Species Res. 30 45-52. https://doi.org/10.3354/ esr00719

HU JY, JIN F, WAN Y, YANG M, AN LH, AN W and TAO S (2005) Trophodynamic behaviour of 4-nonylphenol and nonylphenol polyethoxylates in a marine aquatic food web from Bohai Bay, North China: comparison to DDTs. Environ. Sci. Technol. 39 (13) 4801-4807. https://doi.org/10.1021/es048735h

INOUE K, KONDO S, YOSHIE Y, KATO K, YOSHIMARA Y, HORIE $\mathrm{M}$ and NAKAZAWA H (2001) Migration of 4-nonylphenol from polyvinyl chloride food packaging films into food simulants and foods. Food Add. Contam. 18 (2) 157-164. https://doi. org/10.1080/02652030010018930

JENSEN J and JEPSEN SE (2005) The production, use and quality of sewage sludge in Denmark. Waste Manage. 25 239-247. https://doi. org/10.1016/j.wasman.2004.08.011
JIN XL, JIANG GB, HUANG GL, LIU JF and ZHOU QF (2004) Determination of 4-tert-octylphenol, 4-nonylphenol and bisphenol A in surface waters from the Haihe River in Tianjin by gas chromatography-mass spectrometry with selected ion monitoring. Chemosphere 56 (11) 1113-1119. https://doi.org/10.1016/j. chemosphere.2004.04.052

JOHN DM, HOUSE WA and WHITE GF (2000) Environmental fate of nonylphenol ethoxylates: differential adsorption of homologs to components of river sediment. Environ. Toxicol. Chem. 19 293-300. https://doi.org/10.1002/etc.5620190207

JOHNSON AC, AERNI HR, GERRITSEN A, GIBERT M, GIGER W and HYLLAND K (2005) Comparing steroid oestrogen and nonylphenol content across a range of European sewage plants with different treatment and management practices. Water Res. 39 47-58. https://doi.org/10.1016/j.watres.2004.07.025

KANNAN K, KEITH TL, NAYLOR CG, STAPLES CA, SNYDER SA and GIESY JP (2003) Nonylphenol and nonylphenol ethoxylates in fish, sediment, and water from the Kalamazoo River, Michigan. Arch. Environ. Contam. Toxicol. 44 77-82. https://doi.org/10.1007/ s00244-002-1267-3

KEITH TL, SNYDER SA, NAYLOR CG, STAPLES CA, SUMMER C, KANNAN K, GIESY JP (2001) Identification and quantification of nonylphenol exothylates and nonylphenol in fish tissues from Michigan. Environ. Sci. Technol. 35 10-13. https://doi.org/10.1021/ es001315h

KLOSTERHAUS S, ALLEN RM and DAVIS J (2012) Contaminants of Emerging Concern in the San Francisco Estuary: Alkylphenol Ethoxylates. A Report of the Regional Monitoring Program for Water Quality in the San Francisco Estuary. SFEI Contribution \#657. Final Report. San Francisco Estuary Institute, Richmond, CA.

KOH YKK, CHIU TY, BOOBIS AR, CARTMELL E, POLLARD S, SCHRIMSHAW MD and LESTER JN (2008) A sensitive and robust method for the determination of alkylphenol polyethoxylates and their carboxylic acids and their transformation in a trickling filter treatment plant. Chemosphere 73 (4) 551-556. https://doi. org/10.1016/j.chemosphere.2008.06.016

KONIECKO I, STANISZEWSKA M, FALKOWSKA L, BURSKA D, KIELCZEWSKA J and JASINSKA A (2014) Alkylphenols in surface sediments of the Gulf of Gdansk (Baltic Sea). Water Air Soil Pollut. 225 2040- 2050. https://doi.org/10.1007/s11270-014-2040-8

LA GUARDIA MJ, HALE RC, HAVEY EP and MAINOR TM (2001) Alkylphenol ethoxylates degradation products in land-appliedsewage sludge (biosolids). Environ. Sci. Technol. 35 4789-4804. https://doi.org/10.1021/es0109040

LAI KM, JOHNSON KL, SCHRIMSHAW MD and LESTER NJ (2000) Binding waterbone steroid oestrogens to solid phases in river and estuarine systems. Environ. Sci. Technol. 34 3890-3894. https://doi. org/10.1021/es9912729

LALAH JO, SCHRAMM KW, HENKELMANN B, LENOIR D, BEHECHTI A, GÜNTHER K and KETTRUP A (2003) The dissipation, distribution and fate of a branched 14C-nonylphenol isomer in lake water/sediment systems. Environ. Pollut. 122 195203. https://doi.org/10.1016/S0269-7491(02)00295-6

LANGFORD KH and LESTER NJ (2002) Fate and behavior of endocrine disrupters in sludge treatment and disposal. In: Brickett JW, Lester JN (eds) Endocrine Disrupters in Wastewater and Sludge Treatment Processes. CRC Press, Boca Raton. https://doi. org/10.1201/9781420032185.ch4

LANGFORD KH, SCHRIMSHAW MD, BRIKETT JW and LESTER JN (2005) Degradation of nonylphenolic surfactants in activated sludge batch tests. Water Res. 39 870-876. https://doi.org/10.1016/j. watres.2004.11.033

LANGSTON WJ, BURT GR, CHESMAN BS and VANE CH (2005) Partitioning, bioavailability and effects of oestrogen and xenooestrogens in the aquatic environment. J. Mar. Biol. Ass. UK. $851-31$.

LARA-MARTIN PA, GOMEZ-PARRA A, BARCELÓ D and GONZALEZ-MAZO E (2006) Presence of surfactants and their degradation intermediates in sediments cores and grabs from the Cadiz Bay. Environ. Pollut. 114 483-491. https://doi.org/10.1016/j. envpol.2006.01.033

LI D, KIM M, SHIM WJ, YIM UH, OH JR and KWON YJ (2004) 
seasonal flux of nonylphenol in Han River, Korea. Chemosphere 56 1-6. https://doi.org/10.1016/j.chemosphere.2004.01.034

LI XL, LUAN TG, LIANG Y, WONG MH and LAN CY (2007) Distribution patterns of octylphenol and nonylphenol in the aquatic system at Mai Po Marshes Nature Reserve, a subtropical estuarine wetland in Hong Kong. J. Environ. Sci. 19 657-662. https://doi.org/10.1016/S1001-0742(07)60110-7

LOYO-ROSALES JE, ROSALES-RIVERA GC, LYNCH AM, RICE CP and TORRENTS A (2004) Migration of nonylphenol from plastic containers to water and a milk surrogate. J. Agric. Food Chem. 52 (7) 2016-2020. https://doi.org/10.1021/jf0345696

LOYO-ROSALES JE, RICE CP and TORRENTS A (2007) Fate of octyland nonylphenol ethoxylates and some carboxylates derivatives in three American wastewater treatment plants. Environ. Sci. Technol. 41 6815-6821. https://doi.org/10.1021/es070713i

LU J, WU J, STOFFELLA PJ and WILSON PC (2013) Analysis of Bisphenol A, Nonylphenol and natural oestrogens in vegetables and fruits using gas chromatography-tandem mass spectrometry. J. Agric. Food Chem. 61 84-89. https://doi.org/10.1021/jf304971k

LU YY, CHEN ML, SUNG FC, PAULUS SHYI-GANG W and MAO IF (2007) Daily intake of 4-nonylphenol in Taiwanese. Environ. Int. 33 (7) 903-910. https://doi.org/10.1016/j.envint.2007.04.008

LU Z and GAN J (2014) Analysis, toxicity, occurrence and biodegradation of nonylphenol isomers: Review Environ. Int. 73 334-345. https://doi.org/10.1016/j.envint.2014.08.017

LUO Y, GUO W, NGO HH, NGHIEM LD, HAI FI, ZHANG J, LIANG S and WANG XC (2014) A review on the occurrence of micropollutants in the aquatic environment and their fate and removal during wastewater treatment. Sci. Total Environ. 473474 619-641. https://doi.org/10.1016/j.scitotenv.2013.12.065

MAO Z, ZHENG XF, ZHANG YQ, TAO XX, LI Y and WANG W (2012) Occurrence and biodegradation of nonylphenol in the environment. Int. J. Mol. Sci. 13 491-505. https://doi.org/10.3390/ ijms13010491

MAYER T, BENNIE D, ROSA F, REKAS G, PALABRICA V and SCHACHTSCHNEIDER J (2007) Occurrence of alkylphenolic substances in a Great Lakes coastal marsh, Cootes paradise, ON, Canada. Environ. Pollut. 147 683-690. https://doi.org/10.1016/j. envpol.2006.09.012

MEIER S, MORTON HC, ANDERSSON E, GEFFEN AJ, TARANGER GL, LARSEN M, PETERSEN M, DJURHUUS R, KLUNGSOVR J and SVARDAL A (2011) Low-dose exposure to alkylphenols adversely affects the sexual development of Atlantic cod (Gadus morhua): acceleration of the onset of puberty and delayed seasonal gonad development in mature female cod. Aquat. Toxicol. 105 136150. https://doi.org/10.1016/j.aquatox.2011.06.003

MICIC V and HOFMANN T (2009) Occurrence and behavior of selected hydrophobic alkylphenolic compounds in the Dunabe River. Environ. Pollut. 157 2759-2768. https://doi.org/10.1016/j. envpol.2009.04.028

MOEDER M, MARTIN C, HARYNUK J, GORECKI T, VINKEN $\mathrm{R}$ and CORVINI PFX (2006) Identification of isomeric 4nonylphenol structures by gas chromatography-tandem mass spectrometry combined with cluster analysis. J. Chromatogr. A 1102 (1-2) 245-255. https://doi.org/10.1016/j.chroma.2005.10.031

NAKADA N, TANISHAMA T, SHINOHARA H, KIRI K and TAKADA H (2006) Pharmaceutical chemicals and endocrine disrupters in municipal wastewater in Tokyo and their removal during activated sludge treatment. Water Res. 40 3297-3303. https://doi.org/10.1016/j.watres.2006.06.039

NÚÑEZ L, TURIEL E and TADEO JL (2007) Determination of nonylphenol and nonylphenol ethoxylates in environmental solid samples by ultrasonic-assisted extraction and high performance liquid-chromatography-fluorescence detection. J. Chromatogr. A 1146 157-163. https://doi.org/10.1016/j.chroma.2007.01.101

OLKOWSKA E, RUMAN M and POLKOWSKA Z (2014) Occurrence of surface active agents in the environment. J. Anal. Meth. Chem. 2014 1-15. https://doi.org/10.1155/2014/769708

OLUJIMI OO, FATOKI OS, DASO AP, AKINSOJI OS, OPUTU OU, OLUWEFEMI PS and SONGCA SP (2013) Levels of nonylphenol and bisphenol $\mathrm{A}$ in wastewater treatments plants effluent, sewage sludge and leachates around Cape Town, South Africa. In: Valdez CJ and Maradona EM (eds.) Handbook of Wastewater Treatment.
Nova Science Publisher Inc., New York.

OLUJIMI OO, FATOKI OS, ODENDAAL JP and OKONKWO OJ (2010) Endocrine disrupting chemicals (phenol and phthalates) in the South African environment: a need for more monitoring. Water SA 36 (5) 671-682. https://doi.org/10.4314/wsa.v36i5.62001

OKETOLA AO and FAGBENIGUN TK (2013) Determination of nonylphenol, octylphenol and bisphenol A in water and sediments of two major rivers in Lagos, Nigeria. J Environ. Prot. 4 38-45. https://doi.org/10.4236/jep.2013.47A005

PENG X, WANG Z, YANG C, CHENA F and MAIA B (2006) Simultaneous determination of endocrine disrupting phenols and steroid oestrogens in sediment by gas chromatographymass spectrometry. J. Chromatogr. A 1116 51-56. https://doi org/10.1016/j.chroma.2006.03.017

PETROVIC M, ELJARRAT E, LOPEZ DE ALDA MJ and BARCELÓ D (2002) Recent advances in the mass spectrometric analysis related to endocrine disrupting compounds in aquatic environmental samples. J. Chromatogr. A 974 23-51. https://doi.org/10.1016/ S0021-9673(02)00907-X

PETROVIC M, BARCELÓ D, DIAZ A and VENTURA F (2003) Low Nanogram per liter determination of halogenated nonylphenols, nonylphenol carboxylates, and their non-halogenated precursors in water and sludge by liquid chromatography electrospray tandem mass spectrometry. J. Am. Soc. Mass Spectrom. 14 516-527. https:// doi.org/10.1016/S1044-0305(03)00139-9

POJAN G, GOMIERO A, JONKERS N and MARCOMINI A (2007) Natural and synthetic endocrine disrupting compounds (EDCs) in water, sediment and biota of a coastal lagoon. Environ. Int. 33 929936. https://doi.org/10.1016/j.envint.2007.05.003

REMPEL MA and SCHLENK D (2008) Effects of environmental oestrogens and antiandrogens on endocrine function, gene regulation and health in fish. Int. Rev. Cell Mol. Biol. 267 207-252. https://doi.org/10.1016/S1937-6448(08)00605-9

RENNER R (1997) European bans on surfactant trigger transatlantic debate. Environ. Sci. Technol. 31 316-320. https://doi.org/10.1021/ es972366q

RICE CP, SCHMITZ-ALFONSO I, LOYO-ROSALES JE, LINK E, THOMA R, FA L, ALTFATER D and CAMP MJ (2003) Alkylphenol and Alkylphenol ethoxylates in carp, water and sediment from the Cuyahoga River, Ohio. Environ. Sci. Technol. 37 3747-3754. https://doi.org/10.1021/es034105o

RUDEL RA, MELLY SJ, BRODY JG, GENO PW and SUN G (1998) Identification of alkylphenols and other oestrogenic phenolic compounds in wastewater, septage and groundwater on Cape Cod, Massachusetts. Environ. Sci. Technol. 32 (7) 861-869. https://doi. org/10.1021/es970723r

RUDEL RA, CAMANN DE, SPENGLER J, KORN LR and BRODY JG (2003) Phthalates, alkylphenols, pesticides, polybrominated diphenyl ethers, and other endocrine-disrupting compounds in indoor air and dust. Environ. Sci. Technol. 37 (20) 4543-4553. https://doi.org/10.1021/es0264596

RUDEL RA and PEROVICH LJ (2009) Endocrine disrupting chemicals in indoor and outdoor air. Atmos. Environ. 43 170-181. https://doi. org/10.1016/j.atmosenv.2008.09.025

RUDEL RA, DODSON RE, PEROVICH LJ, MORELLO- FROSCH R, CAMANN DE, ZUNIGA MM, YAU AY, JUST AC and BRODY JG (2010) Semivolatile endocrine disrupting compounds in paired indoor and outdoor air in two Northern California communities. Environ. Sci. Technol. 44 6583-6590. https://doi.org/10.1021/ es100159c

SAITO I, ONUKI A and SETO H (2004) Indoor air pollution by alkylphenols in Tokyo. Indoor Air 14 (5) 325-332. https://doi. org/10.1111/j.1600-0668.2004.00250.x

SALAPASIDOU M, SAMARA C and VOUTSA D (2011) Endocrine disrupting compounds in the atmosphere of the urban area of Thessaloniki, Greece. Atmos. Environ. 45 3720-3729. https://doi. org/10.1016/j.atmosenv.2011.04.025

SCHMITZ-AFONSO I, LOYO-ROSALES JL, DE LA PAZ AVILES M, RATTNER BA and RICE CP (2003) Determination of alkylphenol and alkylphenol ethoxylates in biota by liquid chromatography with detection by tandem mass spectrometry and fluorescence spectroscopy. J. Chromatogr. A 1010 25-35. https://doi.org/10.1016/ S0021-9673(03)00956-7 
SCRIMSHAW MD and LESTER NJ (2002) Fate and behavior of endocrine disrupters in sludge treatment and disposal. In: Brickett JW and Lester JN (eds). Endocrine Disrupters in Wastewater and Sludge Treatment Processes. CRC Press, Boca Raton. https://doi. org/10.1201/9781420032185

SERVOS MR (1999) Review of the aquatic toxicity, oestrogenic responses and bioaccumulation of alkylphenols and alkylphenol polyethoxylates. Water Qual. Res. J. Can. 34 123-177. https://doi. org/10.1080/713609923

SERVOS MR, MAGUIRE RJ, BENNIE DT, LEE H, CURETON PM, DAVIDSON N, SUTCLIFFE R and RAWN DFK (2003) An ecological risk assessment of nonylphenol and its ethoxylates in the aquatic environment. Hum. Ecol. Risk Assess. 9 569-587.

SHANG DY, MACDONALD RW and IKONOMOU MG (1999) Persistence of nonylphenol ethoxylate surfactants and their primary degradation products in sediments from near a municipal outfall in the Strait of Georgia, British Columbia, Canada. Environ. Sci. Technol. 33 1366-1372. https://doi.org/10.1021/es980966z

SHAO B, HU J and YANG M (2003) Nonylphenol ethoxylates and their biodegradation intermediates in water and sludge of a sewage treatment plant. Bull. Environ. Contam. Toxicol. 70 527-532. https://doi.org/10.1007/s00128-003-0018-0

SIBALI LL, OKONKWO JO and MCCRINDLE RI (2010) Levels of selected alkylphenol ethoxylates (APEs) in water and sediment samples from Jukskei River catchment area in Gauteng, South Africa. Water SA 36 (3) 229-238.

SIEMERING GS, HAYWORTH JD and GREENFIELD BK (2008) Assessment of potential aquatic herbicide impacts to California aquatic ecosystems. Arch. Environ. Contam. Toxicol. 55 415-431. https://doi.org/10.1007/s00244-008-9137-2

SOARES A, GUIEYSSE B, JEFFERSON B, CARTMELL E and LESTER JN (2008) Nonylphenol in the environment: A critical review on occurrence, fate, toxicity and treatment in wastewaters. Environ Int. 34 1033-1049. https://doi.org/10.1016/j.envint.2008.01.004

STAPLES C, MIHAICH E, CARBONE J, WOODBURN K and KLECKA G (2004) A weight of evidence analysis of the chronic ecotoxicity of nonylphenol ethoxylates, nonylphenol ether carboxylates, and nonylphenol. Hum. Ecol. Risk Assess. 10 9991017. https://doi.org/10.1080/10807030490887122

STASINAKIS AS, GATIDOU G, MAMAIS D, THOMAIDIS NS and LEKKAS TD (2008) Occurrence and fate of endocrine disrupters in Greek sewage treatment plants. Water Res. 42 1976-1804. https:// doi.org/10.1016/j.watres.2007.11.003

STEHMANN A and SCHRÖDER HF (2004) Derivatization of 4-nonylphenol and bisphenol A with halogenated anhydrides Water Sci. Technol. 50 (5) 115-118.

SWARTZ CH, REDDY S, BENOTTI MJ, YIN H, BARBER LB, BROWNAWELL BJ, RUDEL RA (2006) Steroid oestrogens, nonylphenol ethoxylate metabolites, and other wastewater contaminants in groundwater affected by a residential septic system on Cape Cod, MA. Environ. Sci. Technol. 40 (16) 4894 4902. https://doi.org/10.1021/es052595+

TSUDA T, SUGA K, KANEDA E and OHSUGA M (2002) 4-nonylphenol, 4-nonylphenol mono- and diethoxylates and other 4-alkylphenols in water and shellfish from rivers following into Lake Biwa. Bull. Environ. Contam. Toxicol. 68 (1) 126-131. https:// doi.org/10.1007/s00128-001-0228-2

UGUZ C, ISCAN M, ERGÜVEN A, ISGOR B and TOGAN I (2003) The bioaccumulation of nonylphenol and its adverse effect on the liver of rainbow trout (Onchorynchus mykiss). Environ. Res. 92 (2) 262-270. https://doi.org/10.1016/S0013-9351(03)00033-1

USEPA (United States Environmental Protection Agency) (2005) Ambient Aquatic Life Water Quality Criteria - Nonylphenol Final. Office of Water, Office of Science and Technology, USEPA, Washington, DC. EPA-822-R-05-005. URL: http.//water.epa. gov/scitech/swguidance/standards/criteria/aqlife/nonylphenol/ upload/2006_5_18_criteria_nonylphenol_final-doc.pdf (Accessed 27 January 2017).

VAN MILLER JP and STAPLES CA (2005) Review of the potential environmental and human health-related hazard and risks from long term exposure to p-tert-octylphenol. Hum. Ecol. Risk Assess. 11 319-351. https://doi.org/10.1080/10807030590925812

VAN RY D, DACHS J, GIGLIOTTI C, BRUNCIAK P, NELSON E and EISENREICH S (2000) Atmospheric seasonal trends and environmental fate of alkylphenols in lower Hudson River estuary. Environ. Sci. Technol. 34 2410-2417. https://doi.org/10.1021/ es9910715

VAZQUEZ-DUHALT R, MARQUEZ-ROCHA F, PONCE E, LICEA AF and VIANA MT (2005) Nonylphenol, an integrated vision of a pollutant. Scientific review. Appl. Ecol. Environ. Res. 4 1-25. https:// doi.org/10.15666/aeer/0401_001025

VERSLYCKE TA, VETHAAK AD, ARIJS K and JANSSEN CR (2005) Flame retardants, surfactants and organotin in sediments and mysid shrimp of the Scheldt estuary (The Netherlands). Environ. Pollut. 136 19-31. https://doi.org/10.1016/j.envpol.2004.12.008

WANG J, DONG M, SHIM WJ, KANNAN K and LI D (2007) Improved cleanup technique for gas chromatographic-mass spectrometric determination of alkylphenols from biota extract. J. Chromatogr. A 117 (1-2) 15-21. https://doi.org/10.1016/j. chroma.2007.09.043

WANG J, SHIM WJ, YIM UH, KANNAN N and LI D (2010) Nonylphenol in bivalves and sediments in northeast coast of China. J. Environ. Sci. 22 (11) 1735-1740. https://doi.org/10.1016/ S1001-0742(09)60313-2

WANG L, YING GG, CHEN F, ZHANG LJ, ZHAO JL, LAI HJ, CHEN ZF and TAO R (2012) Monitoring of selected oestrogenic compounds and oestrogenic activity in surface water and sediment of the Yellow River in China using combined chemical and biological tools. Environ. Pollut. 165 241-249. https://doi. org/10.1016/j.envpol.2011.10.005

WHITE R, HOARE SA, PARKER MG, JOBLING S and SUMPTER JP (1994) Environmentally persistent alkylphenolic compounds are oestrogenic. Endocrinology 135 (1) 175-182. https://doi.org/10.1210/ endo.135.1.8013351

WHO (World Health Organization) (2004) Integrated risk assessment: Nonylphenol case study. International programme on chemical safety. World Health Organization. URL: www.who.int/ipcs/ methods/Nonylphenol.pdf. Accessed 27 January 2016.

WILSON NK, CHUANG JC and LYU C (2001) Levels of persistent organic pollutants in several child day care centers. J. Exposure Anal. Environ. Epidemiol. 11 (6) 449-458. https://doi.org/10.1038/ sj.jea.7500190

WU ZY, ZENG ZD and MARRIOTT PJ (2010) Comparative qualitative analysis of nonylphenol isomers by gas chromatography-mass spectrometry combined with chemometric resolution. J. Chromatogr. A 1217 (49) 7759-7766. https://doi.org/10.1016/j. chroma.2010.10.024

XIE Z, LAKASCHUS S, EBINGHAUS R, CABA A and RUCK W (2006) Atmospheric concentrations and air-sea exchanges of nonylphenol and nonylphenol monoethoxylate in the North Sea. Environ. Pollut. 142 170-180. https://doi.org/10.1016/j. envpol.2005.08.073

XIE $Z$ and EBINGHAUS R (2008) Analytical methods for the determination of emerging organic contaminants in the atmosphere. Anal. Chim. Acta 610 156-178. https://doi. org/10.1016/j.aca.2008.01.055

XIE XY, LÜ WJ and CHEN XG (2013) Binding of the endocrine disruptors 4-tert-octylphenol and 4-nonylphenol to human serum albumin. J. Hazardous Mater. 248-249 347-354. https://doi. org/10.1016/j.jhazmat.2013.01.036

XU EGB., LIU S, YING GG, ZHENG GJS, LEE JHW and LEUNG KMY (2014) The occurrence and ecological risks of endocrine disrupting chemicals in sewage effluents from three different sewage treatment plants, and in natural seawater from a marine reserve of Hong Kong. Mar. Pollut. 85 352-362. https://doi. org/10.1016/j.marpolbul.2014.02.029

XU J, WANG P, GUO WF, DONG JX, WANG L and DAI SG (2006) Seasonal and spatial distribution of nonylphenol in Lanzhou Reach of Yellow River in China. Chemosphere 65 1445-1451. https://doi. org/10.1016/j.chemosphere.2006.04.042

YING GG, WILLIAMS B and KOOKANA R (2002) Environmental fate of alkylphenols and alkylphenol ethoxylates- a review. Environ. Int. 28 215-226. https://doi.org/10.1016/S0160-4120(02)00017-X YING GG (2006) Fate, behavior and effects of surfactants and their degradation products in the environment. Environ. Int. 32 417-431. https://doi.org/10.1016/j.envint.2005.07.004 
YING GG, KOOKANA RS and KUMAR A (2008) Fate of oestrogens and xenooestrogens in four sewage treatment plants with different technologies. Environ. Toxicol. Chem. 27 87-94. https://doi. org/10.1897/07-046.1

YING GG, KOOKANA RS, KUMAR A and MORTIMER M (2009) Occurrence and implications of oestrogens and xenooestrogens in sewage effluents and receiving waters from South East Queensland. Sci. Total Environ. 407 5147-5155. https://doi.org/10.1016/j. scitotenv.2009.06.002

ZHANG YZ, TANG CY, SONG XF and LI FD (2009) Behavior and fate of alkylphenols in surface water of Jialu River, Henan Province,
China. Chemosphere 77 559-565. https://doi.org/10.1016/j. chemosphere.2009.07.005

ZHOU Q, GAO Y and XIE G (2011) Determination of bisphenol A, 4-n-nonylphenol, and 4-tert-octylphenol by temperature-controlled ionic liquid dispersive liquid-phase microextraction combined with high performance liquid chromatography-fluorescence detector. Talanta 85 1598-1602. https://doi.org/10.1016/j.talanta.2011.06.050 ZHUO Z and ZUO Y (2013) Bisphenol A and other alkylphenols in the environment- occurrence, fate, health effects and analytical techniques. Adv. Environ. Res. 2 (3) 179-202. https://doi. org/10.12989/aer.2013.2.3.179 